\title{
Analisis Pelayanan Administrasi Kependudukan pada Dinas Kependudukan dan Pencatatan Sipil Kabupaten Dairi
}

\section{Analysis of Population Administration Services at the Department of Population and Civil Registration of Dairi Regency}

\author{
Koko Mulyanto Angkat ${ }^{1}$, Abdul Kadir ${ }^{2}$, Isnaini ${ }^{3}$ \\ 1 Program Studi Magister Administrasi Publik Universitas Medan Area, Indonesia. \\ 2 Fakultas Ilmu Sosial dan Ilmu Politik, Universitas Medan Area, Indonesia. \\ 3 Fakultas Hukum, Universitas Medan Area, Indonesia. \\ *corresponding author: email : effendihud@yahoo.com
}

\begin{abstract}
Abstrak
Penelitian ini bertujuan untuk mengetahui Analisis Pelaksanaan Administrasi Kependudukan pada Dinas Kependudukan dan Pencatatan Sipil Kabupaten Dairi. Penelitian ini adalah penelitian deskriptif dengan menggunakan pendekatan kualitatif. Teknik pengumpulan data dilakukan dengan teknik observasi, wawancara, dan telaah dokumen. Dari hasil penelitian menunjukkan bahwa (1) pelayanan pendaftaran penduduk pada Dinas Kependudukan dan Pencatatan Sipil Kabupaten Dairi sudah berjalan dengan baik dalam hal persyaratan, prosedur, dan biaya/ tarif sesuai dengan Peraturan Menteri Pendayagunaan Aparatur Negara dan Reformasi Birokrasi Nomor 15 Tahun 2014 tentang Pedoman Standar Pelayanan. Adapun yang menjadi kendala adalah dalam hal jangka waktu, produk pelayanan, dan penanganan pengaduan. (2) Pelayanan pencatatan sipil sudah berjalan baik dalam hal persyaratan, biaya/tarif sesuai dengan Permenpan dan RB Nomor 15 Tahun 2014 tentang Pedoman Standar Pelayanan, adapun kendala pelayanan adalah dalam hal prosedur, jangka waktu, produk pelayanan, dan penanganan pengaduan. (3)pelaksanaan Sistem Informasi Administrasi Kependudukan (SIAK) belum berjalan dengan baik dan belum sesuai dengan Permenpan dan RB Nomor 15 Tahun 2014 tentang Pedoman Standar Pelayanan dalam hal sarana dan prasarana, kompetensi pelaksana, dan jumlah pelaksana.
\end{abstract}

Kata Kunci: Analisis, Pendaftaran Penduduk, Pencatatan Sipil.

Abstract

This study aims to find out the Implementation Analysis of Population Administration at the Department of Population and Civil Registration of Dairi Regency. This research is descriptive research using qualitative approach. Technique of data collecting is done by observation technique, interview, and document review. The result of the research shows that (1) the service of population registration at the Department of Population and Civil Registration of Dairi Regency has been running well in terms of requirements, procedures and cost / tariff in accordance with the Regulation of the Minister of Administrative Reform and Bureaucratic Reform Number 15 Year 2014 on Standard Guideline Service. The obstacles are in terms of time period, product service, and complaint handling. (2) Civil registration service is already in good condition in terms of terms, tariff / tariff pursuant to Permenpan and RB Number 15 Year 2014 on Standard Service Guidelines, while service constraints are in terms of procedure, duration, product of service, and complaint handling. (3) the implementation of Information System of Population Administration (SIAK) has not run well and not in accordance with Permenpan and RB Number 15 Year 2014 about Guideline of Service Standard in terms of facilities and infrastructure, implementing competence, and number of implementers.

Keywords: Analysis, Population Registration, Civil Registration.

How to Cite: Angkat, K.M., Abdul K., Isnaini, (2016), Analisis Pelayanan Administrasi Kependudukan pada Dinas Kependudukan dan Pencatatan Sipil Kabupaten Dairi, Jurnal Administrasi Publik, 7 (1): 33-48 


\section{PENDAHULUAN}

Indonesia merupakan salah satu Negara dengan jumlah penduduk yang paling besar di dunia. Sesuai dengan data Direktorat Jenderal Administrasi Kependudukan (Dirjen Adminduk) Kementerian Dalam Negeri Republik Indonesia, jumlah penduduk Indonesia per 30 Juni 2016 adalah sebesar 257.912.349 jiwa. Dengan jumlah penduduk yang besar seperti ini, Indonesia tentunya membutuhkan administrasi kependudukan yang terorganisir dari pusat hingga ke daerah. Administrasi kependudukan dimaksud menyangkut seluruh masalah kependudukan, yang meliputi pendaftaran penduduk, pencatatan sipil, dan pengelolaan informasi kependudukan.

Administrasi Kependudukan menjadi semakin penting karena selalu bersentuhan dengan setiap aktivitas kehidupan di Indonesia. diantaranya adalah saat pemilu legislatif, pemilu presiden, pemilu kepala daerah, mengurus surat-surat kendaraan, mengurus surat-surat tanah, dan aktivitas lainnya. Apabila kita akan berdomisili pada suatu wilayah maka kita harus memiliki tanda domisili yang dibuktikan dengan Kartu Tanda Penduduk.

Terkait dengan hal tersebut, pemerintah telah mengeluarkan kebijakan kependudukan melalui Undang-undang Republik Indonesia Nomor 23 Tahun 2006 tentang Administrasi Kependudukan. Dalam kebijakan ini, yang dimaksud dengan administrasi kependudukan adalah kegiatan penataan dan penertiban dalam penerbitan dokumen dan data kependudukan melalui Pendaftaran Penduduk, Pencatatan Sipil, Pengelolaan informasi Administrasi Kependudukan serta pendayagunaan hasilnya untuk pelayanan publik dan pembangunan sektor lain.

Seiring dengan perkembangan zaman yang dinamika perubahannya sangat cepat, maka dibutuhkan pelayanan Administrasi Kependudukan yang semakin profesional, memenuhi standar teknologi informasi, dinamis, tertib, dan tidak diskriminatif, akhirnya pemerintah melakukan penyesuaian terhadap beberapa ketentuan dalam Undang-Undang Nomor 23 Tahun 2006 tentang Administrasi Kependudukan. Perubahan dimaksud melahirkan Undang-Undang Nomor 24 tahun 2013 Tentang Perubahan Atas Undang-Undang Nomor 23 tahun 2006 Tentang Administrasi Kependudukan. Karena sifatnya yang revisi, maka yang berubah dari Undang-Undang Nomor 23 tahun 2006 tentang Administrasi Kependudukan ke Undang-Undang Nomor 24 tahun 2013 Tentang Perubahan Atas Undang-Undang No. 23 tahun 2006 Tentang Administrasi Kependudukan adalah sebahagian kecil yang dianggap sudah tidak relevan untuk saat ini dan perlu disesuaikan. Perubahan itu meliputi ketentuan umum, Kewenangan Penyelenggara dan Instansi Pelaksana, Pencatatan Sipil, Data dan Dokumen Kependudukan. Adapun perubahan dimaksud diharapkan akan semakin mempermudah masyarakat dalam proses administrasi kependudukannya. Disamping itu biaya dalam proses pengurusan administrasi kependudukan adalah gratis atau tidak dipungut bayaran.

Demikian halnya di Kabupaten Dairi, dimana Dinas Kependudukan dan Pencatatan Sipil Kabupaten Dairi sebagai instansi teknis penyelenggara pemerintahan di bidang administrasi 
kependudukan di Kabupaten Dairi berkewajiban melaksanakan tugas pokok dan fungsinya sesuai dengan Peraturan Bupati Dairi Nomor Nomor 05 Tahun 2008 Tentang Organisasi dan Tata Kerja Sekretariat Daerah, Sekretariat DPRD, Kantor Kecamatan, Dinas dan Lembaga Teknis Lainnya. Sesuai dengan data yang diperoleh dari Dinas Kependudukan dan Pencatatan Sipil Kabupaten Dairi, jumlah penduduk Kabupaten Dairi per Desember 2016 adalah sebesar 320.881 jiwa. Dalam hal menangani proses administrasi kependudukan di Kabupaten Dairi, maka Pemerintah Kabupaten Dairi telah mengeluarkan Peraturan Bupati Dairi Nomor 03 Tahun 2010 tentang Pedoman dan Tata Cara Pendaftaran Penduduk dan Pencatatan Sipil di Kabupaten Dairi.

Namun dalam pelaksanaannya, proses administrasi kependudukan di Kabupaten Dairi masih mengalami berbagai kendala dan permasalahan. Berdasarkan pengamatan awal yang telah dilakukan di Dinas Kependudukan dan Pencatatan Sipil Kabupaten Dairi, masyarakat sering mengeluhkan pelayanan dari petugas yang terkesan menyulitkan padahal peraturan dan perundang-undangan yang berlaku bertujuan untuk semakin memudahkan proses pelayanan publik. Permasalahan dalam hal kurang lengkapnya berkas persyaratan menjadi hal yang sering ditemui. Hal ini dikarenakan kurangnya informasi dari Dinas Kependudukan dan Pencatatan Sipil Kabupaten Dairi mengenai persyaratan yang dibutuhkan. Sementara dari segi infrastruktur, ruangan yang dijadikan sebagai tempat menunggu (ruang tunggu) bagi masyarakat yang akan mengurus dokumen kependudukannya cukup sempit dan relativ kurang layak sebagai unsur pelayanan prima. Sehingga sangat sering dijumpai masyarakat yang berdesak- desakan pada ruangan dimaksud. Hal ini dimungkinkan karena karena gedung kantor Dinas Kependudukan dan Pencatatan Sipil Kabupaten Dairi merupakan bangunan lama yang didirikan pada tahun 1969 sesuai dengan laporan Barang Milik Daerah Dinas Kependudukan dan Pencatatan Sipil Kabupaten Dairi Tahun 2016.

Keluhan lain dari masyarakat adalah kurangnya sosialisasi terkait masa berlaku Kartu Tanda Penduduk Elektronik (KTP-el), dimana masyarakat masih ragu apakah tetap berlaku selama 5 (lima) tahun, atau berlaku seumur hidup. Padahal Menteri Dalam Negeri Republik Indonesia telah mengeluarkan Surat Edaran Nomor 470/295/SJ tanggal 29 Januari 2016 perihal KTP Elektronik (KTP-el) berlaku Seumur Hidup yang ditujukan bagi Gubernur, Bupati/ Walikota seluruh Indonesia agar segera disosialisasikan. Terkait dengan penerbitan KTP Elektronik, kurangnya sosialisasi mengenai belum adanya pengadaan blanko KTP-el dari Direktorat Jendral Administrasi Kependudukan hingga Maret 2017, juga meresahkan masyarakat. Padahal hal ini sudah menjadi permasalahan nasional, namun perlu sosialisasi yang lebih intensif dari Dinas Kependudukan dan Pencatatan Sipil Kabupaten Dairi agar masyarakat Kabupaten Dairi dapat lebih memahaminya.

Permasalahan lain yang juga sering dijumpai di Dinas Kependudukan dan Pencatatan Sipil Kabupaten Dairi adalah keterlambatan proses penerbitan dokumen kependudukan seperti Kartu Tanda Penduduk Elektronik (KTP-el), Kartu Keluarga (KK), Surat Keterangan Pindah 
(SKP), Akta Catatan Sipil dan dokumen kependudukan lainnya. Keterlambatan Dokumen Kependudukan ini dapat disebabkan oleh kurang lengkapnya berkas pemohon sebagaimana yang disyaratkan, ketersediaan blangko dokumen kependudukan, dan rusaknya peralatan yang dimiliki oleh Dinas Kependudukan dan Pencatatan Sipil Kabupaten Dairi.

\section{METODE PENELITIAN}

Pelaksanaan penelitian ini bertempat di Dinas Kependudukan dan Pencatatan Sipil Kabupaten Dairi, jalan Rumah Sakit Umum No.1 Sidikalang, Kelurahan Batang Beruh, Kecamatan Sidikalang. Penelitian ini dilaksanakan sejak tanggal 20 Pebruari sampai dengan tanggal 6 Maret 2017.

Jenis penelitian yang digunakan dalam penelitian ini adalah metode kualitatif deskriptif, dimana penulis mengumpulkan informasi dari fakta-fakta yang terjadi di organisasi kemudian mengolah menjadi kalimat.

Adapun alasan penulis menggunakan metode penelitian kualitatif deskriptif ini adalah mengambarkan dan menjelaskan hasil-hasil temuan di lapangan yang akan dituangkan dalam bentuk tesis.

Adapun sumber data dalam penelitian ini adalah 1) Data primer, yaitu data yang diperoleh dengan melakukan wawancara langsung kepada informan kunci dan informan pendukung; 2) Data sekunder, yaitu data yang diperoleh dari dokumendokumen yang berkaitan dengan pembahasan, literature, serta sumber lainnya yang berkaitan dengan objek penelitian.

Adapun teknik pengumpulan data dalam penelitian, pertama adalah
Wawancara, wawancara merupakan komunikasi verbal secara langsung dengan informan penelitian yang bertujuan untuk mendapatkan sejumlah informasi yang berkaitan dengan pelaksanaan pendaftaran penduduk, pelaksanaan pencatatan sipil, serta pelaksanaan sistem informasi administrasi kependudukan pada Dinas Kependudukan dan Pencatatan Sipil. Informan dalam penelitian ini sebanyak 10 orang, dimana 1 orang merupakan informan kunci dan 9 orang adalah informan pendukung.

Kedua adalah observasi yang digunakan dengan maksud untuk mengamati dan mencatat gejala-gejala yang tampak pada obyek penelitian pada saat keadaan atau situasi yang dialami atau sebenarnya sedang berlangsung, meliputi pendaftaran penduduk, pencatatan sipil, dan pelaksanaan Sistem Informasi Administrasi Kependudukan (SIAK) pada Dinas Kependudukan dan Pencatatan Sipil Kabupaten Dairi. Hal ini dimaksudkan agar diperoleh data yang lebih mendekati kebenaran yaitu dengan membandingkan hasil wawancara dengan keadaan yang sebenarnya.

Ketiga adalah telaah dokumen yang merupakan teknik pengumpulan data yang berupa laporan, surat resmi, dan peraturan perundang-undangan yang berlaku serta arsip yang mempunyai kaitan dengan permasalahan penelitian. Teknik ini dilakukan dengan membaca, menelaah, dan menganalisa dokumen-dokumen yang relevan dan berkaitan langsung dengan materi permasalahan penelitian dalam hal ini adalah sumber-sumber tertulis lainnya seperti data statistik, produk peraturan perundang-undangan dan kebijakan- 
kebijakan lainnya yang relevan dengan administrasi kependudukan.

Teknik analisis data dalam penelitian ini dilakukan analisis data, dimana data yang telah terkumpul dari hasil wawancara, observasi, dan telaah dokumen digunakan sebagai dasar dalam mendeskripsikan atau menggambarkan keadaan yang sebenarnya.

Analisis data merupakan proses penyederhanaan data ke dalam bentuk yang lebih mudah dibaca dan diinterpretasikan kemudian dilanjutkan dengan tahap check dan recheck.

Maka selanjutnya adalah sampai pada tahap kesimpulan akhir yang menggambarkan bagaimanakah pelaksanaan administrasi kependudukan pada Dinas Kependudukan dan Pencatatan Sipil Daerah Kabupaten Dairi.

\section{HASIL DAN PEMBAHASAN}

Dari hasil wawancara terkait persyaratan pendaftaran penduduk, disimpulkan bahwa persyaratan pendaftaran penduduk pada Dinas Kependudukan dan Pencatatan Sipil Kabupaten Dairi sangat mudah, dan jelas dan berdasarkan Peraturan Bupati Dairi Nomor 03 Tahun 2010 tentang Pedoman dan Tata Cara Pendaftaran Penduduk dan Pencatatan Sipil di Kabupaten Dairi.

Dari hasil telaah dokumen diperoleh data terkait dengan persyaratan pendaftaran penduduk pada Dinas Kependudukan dan Pencatatan Sipil Kabupaten Dairi meliputi persyaratan penerbitan Kartu Keluarga (KK), Kartu Tanda Penduduk elektronik (KTP-el), dan Surat Keterangan Pindah datang sebagai berikut: Syarat Penerbitan KK baru bagi penduduk yang belum mempunyai NIK; Mengisi formulir biodata kependudukan dengan menggunakan formulir model F1.01; Mengisi formulir permohonan $\mathrm{KK}$ dengan menggunakan formulir model F1.06; Melampirkan photokopi atau menunjukkan asli kutipan akta nikah/akta perkawinan bagi penduduk yang sudah menikah; dan Melampirkan surat keterangan pindah/ surat keterangan pindah datang dalam wilayah NKRI.

Syarat Penerbitan KK baru bagi penduduk yang telah mempunyai NIK : Mengisi formulir permohonan KK dengan menggunakan formulir model F-1.06; Melampirkan photokopi KK lama yang sudah memiliki NIK; Melampirkan photokopi atau menunjukkan asli kutipan akta nikah/akta perkawinan bagi penduduk yang sudah menikah; dan Melampirkan photokopi KTP-EL yang sudah memiliki NIK.

Syarat Penerbitan KK karena adanya penambahan anggota keluarga: Melampirkan dan menyerahkan KK lama; Mengisi formulir biodata penduduk dengan menggunakan formulir model F-1.03; dan Melampirkan photokopi akta kelahiran anggota keluarga yang tambah.

Syarat Penerbitan KK karena pengurangan anggota keluarga : Melampirkan dan menyerahkan KK lama; Melampirkan surat keterangan kematian; atau Melampirkan surat keterangan pindah/surat keterangan pindah datang bagi penduduk yang pindah datang dalam wilayah NKRI

Syarat Penerbitan KK karena penambahan anggota keluarga untuk menumpang KK: Melampirkan dan menyerahkan KK lama; Melampirkan dan menyerahkan KK yang menjadi tujuan/yang akan ditumpangi; dan Surat keterangan 
datang dari luar negeri bagi wni yang datang dari luar negeri karena pindah.

Syarat Penerbitan KK karena hilang atau rusak: Surat keterangan hilang dari Kepala Desa/Lurah; Melampirkan dan menyerahkan KK yang menjadi tujuan/yang akan ditumpangi; Melampirkan dan menyerahkan KK yang rusak; Melampirkan photokopi atau menunjukkan dokumen kependudukan dari salah satu anggota keluarga.

Syarat Penerbitan KTP-el baru: Telah berusia 17 tahun, atau sudah kawin atau pernah kawin; Melampirkan surat pengantar dari kepala desa/lurah; Melampirkan photokopi kartu keluarga; Menunjukkan asli kutipan akta nikah/akta perkawinan bagi penduduk yang sudah menikah/pernah menikah namun belum berusia 17 tahun; Melampirkan photokopi akta kelahiran; Formulir permohonan KTPel dengan menggunakan Formulir model F1.07; dan Blangko KTP-el bagi penduduk WNI dan Orang Asing Tinggal Tetap dengan bahan dasar kertas sekuriti dengan menggunakan Formulir model B-1.02.

Syarat Penerbitan KTP-el baru karena hilang atau rusak: Melampirkan surat keterangan kehilangan dari kepolisian atau menunjukkan dan menyerahkan KTP-el yang telah rusak; dan Melampirkan photokopi KK lama yang sudah memiliki NIK.

Syarat Penerbitan KTP-el baru karena terjadinya perubahan data penduduk: Melampirkan dan menyerahkan KK yang telah memiliki NIK; Menyerahkan KTP-el yang lama; Melampirkan surat keterangan/bukti perubahan peristiwa kependudukan dan atau perisitiwa penting.
Syarat Penerbitan KTP-el baru karena pindah datang: Melampirkan dan menyerahkan surat keterangan pindah/ surat keterangan pindah datang yang telah ditandatangani pejabat yang berwenang di tempat kedatangan/tujuan; dan Menyerahkan KTP-el yang lama.

Syarat Penerbitan surat keterangan pindah datang antar desa/kelurahan dalam satu kecamatan: Di tempat asal: Mengisi dan menandatangani formulir permohonan pindah dengan Formulir model F- 1.08; Melampirkan KK dan KTP asli; Kepala desa/kelurahan mengetahui dan membubuhkan tanda tangan.

Di tempat tujuan: Penduduk melaporkan kedatangannya kepada Kepala Desa/Lurah tempat tujuan dengan menunjukkan Surat Keterangan Pindah dari tempat asal; Mengisi dan menandatangani formulir pindah datang; Kepala desa/lurah menandatangani Surat Keterangan Pindah Datang

Syarat Penerbitan surat keterangan pindah antar kecamatan dalam kabupaten:

Di tempat Asal: Mengisi dan menandatangani formulir permohonan pindah dengan Formulir model F- 1.08. 2); Melampirkan KK dan KTP asli; Kepala Desa/Lurah mengetahui dan membubuhkan tanda tangan; Camat menandatangani surat keterangan pindah atas nama Kepala Dinas.

Di tempat tujuan: Penduduk melaporkan kedatangannya kepada Kepala Desa/Lurah tempat tujuan dengan menunjukkan Surat Keterangan Pindah dari tempat asal; Mengisi dan menandatangani formulir pindah datang; Kepala Desa/Lurah menandatangani Surat Keterangan Pindah Datang dan meneruskan formulir permohonan pindah datang kepada Camat; 
Camat menandatangani Surat Keterangan Pindah Datang atas nama kepala Dinas, dengan menembuskan kepada Dinas Kependudukan dan Pencatatan Sipil; Setelah ditandatanganinya Surat Keterangan Pindah Datang oleh camat, Dinas Kependudukan dan Pencatatan Sipil melakukan penarikan terhadap KK dan KTP yang bersangkutan untuk diadakan pergantian sesuai dengan tempat domisili yang baru

Syarat Penerbitan surat keterangan pindah antar kabupaten/propinsi: Mengisi dan menandatangani formulir permohonan pindah; Melampirkan KK dan KTP asli; Kepala Desa/Lurah dan Camat menandatangani formulir permohonan pindah sebagai dasar penerbitan Surat Keterangan Pindah oleh Kepala Dinas; Dinas Kependudukan dan Pencatatan Sipil menerbitkan dan Surat Keterangan Pindah serta menyerahkan kepada penduduk.

Syarat Penerbitan Surat Keterangan Pindah Datang bagi penduduk yang pindah dari luar kabupaten/propinsi: Penduduk yang pindah datang melaporkan perpindahan dan kedatangannya kepada kepala desa/lurah dengan menunjukkan Surat Keterangan Pindah yang ditandatangani oleh instansi pelaksana ditempat asalnya; Kepala Desa/Lurah dan camat secara berjenjang menandatangani formulir permohonan pindah datang penduduk yang pindah datang tersebut, dengan tembusan kepada Dinas Kependudukan dan Pencatatan Sipil; Berdasarkan surat keterangan yang telah ditandatangani oleh Camat, Dinas Kependudukan dan Pencatatan Sipil melakukan pengisian biodata penduduk yang pindah datang tersebut dengan mempergunakan formulir F-1.01; Setelah pengisian biodata kependudukan, Dinas Kependudukan dan Pencatatan Sipil menerbitkan KK dan KTP yang baru sesuai dengan tempat tujuan/domisili penduduk yang bersangkutan.

Berdasarkan hasil wawancara terkait prosedur pendaftaran penduduk, disimpulkan bahwa prosedur pendaftaran penduduk Prosedur pelayanan administrasi kependudukan pada Dinas Kependudukan dan Pencatatan Sipil Kabupaten Dairi dilaksanakan berdasarkan Peraturan Bupati Dairi Nomor 03 Tahun 2010 tentang Pedoman dan Tata Cara Pendaftaran Penduduk dan Pencatatan Sipil di Kabupaten Dairi. Prosedur pelayanan telah dilaksanakan dengan baik oleh aparatur pelaksana dan dirasakan mudah oleh masyarakat sebagai penerima layanan.

Gambar 1. Prosedur Penerbitan KK dan Surat Keterangan Pindah Datang

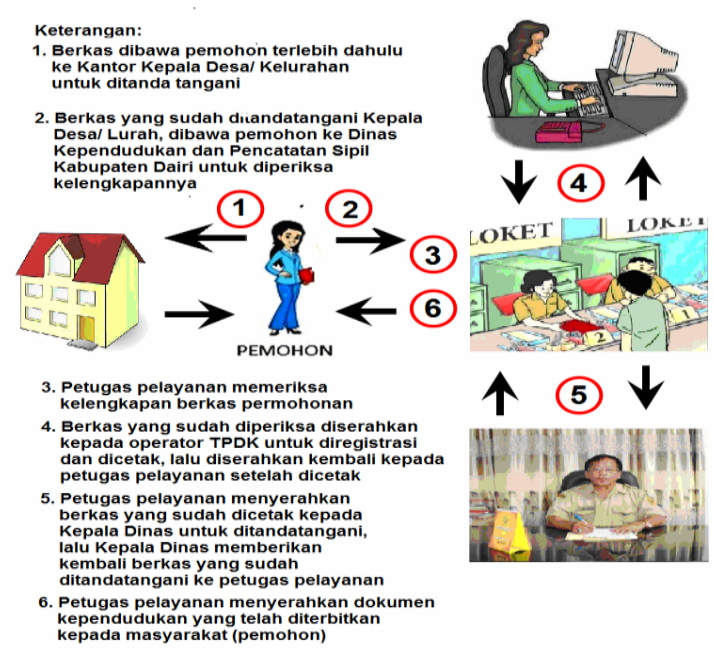

Sumber : Dinas Kependudukan dan Pencatatan Sipil Kabupaten Dairi, 2017

Gambar 1. menjelaskan bahwa prosedur permohonan Kartu Keluarga (KK) harus melalui Kantor Kepala Desa/Kelurahan setempat terlebih dahulu untuk mendapat pengesahan. Selanjutnya masyarakat dapat membawa berkas yang sudah ditanda tangani oleh Kepala Desa/Lurah ke petugas pemeriksa berkas 
yang ada di Kecamatan masing-masing ataupun langsung ke Dinas Kependudukan dan Pencatatan Sipil Kabupaten Dairi. Untuk Surat Keterangan Pindah, selain harus melaporkan kepindahannya kepada Kepala Desa/Lurah setempat, pemohon juga harus melaporkan kepindahannya kepada Camat di Kecamatan masing-masing.

Gambar 2. Prosedur Penerbitan Kartu Tanda Penduduk elektronik (KTP-el)

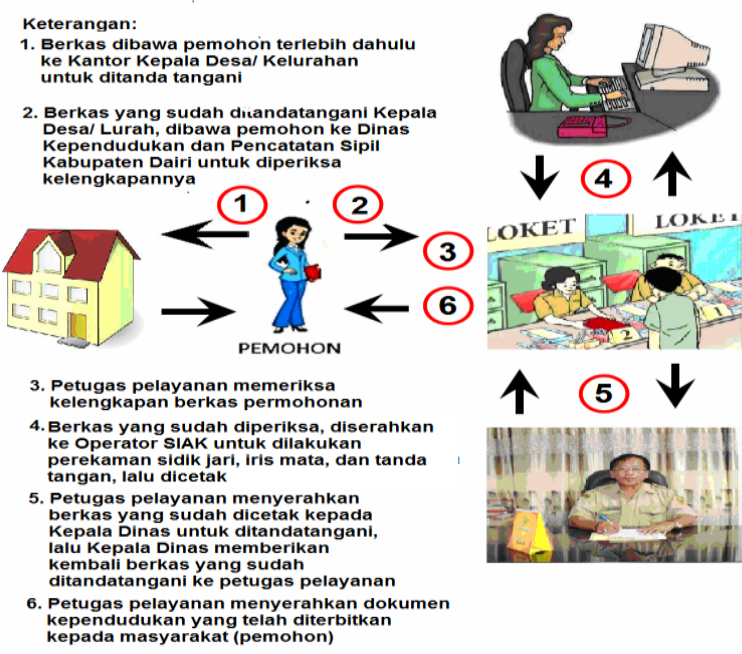

Sumber : Dinas Kependudukan dan Pencatatan Sipil Kabupaten Dairi, 2017

Gambar 2. menjelaskan bahwa permohonan Penduduk elektronik (KTP-el), harus ditanda tangani oleh Kepala Desa/Lurah setempat terlebih dahulu, untuk kemudian direkam datanya pada TPDK Kecamatan masing-masing ataupun langsung melakukan perekaman data di Dinas Kependudukan dan Pencatatan Sipil Kabupaten Dairi.

Berdasarkan hasil wawancara, maka diambil kesimpulan bahwa jangka waktu pelayanan pendaftaran penduduk pada Dinas Kependudukan dan Pencatatan Sipil Kabupaten Dairi adalah 14 hari kerja sesuai Peraturan Bupati Dairi Nomor 03 Tahun 2010 tentang Pedoman dan Tata Cara
Pendaftaran Penduduk dan Pencatatan Sipil di Kabupaten Dairi.

Penerbitan dokumen kependudukan dan akta catatan sipil oleh Dinas Kependudukan dan Pencatatan Sipil Kabupaten Dairi sering mengalami keterlambatan dalam penerbitannya sejak dimohonnkan oleh pemohon atau lebih dari 14 hari kerja. Hal ini disebabkan oleh proses penandatanganan Kartu Keluarga (KK) yang harus ditanda tangani oleh Kepala Dinas Kependudukan dan Pencatatan Sipil Kabupaten Dairi dan tidak dapat diwakilkan, sementara untuk keterlambatan Kartu Tanda Penduduk elektronik (KTP-el) disebabkan oleh tidak tersedianya blangko KTP-el pada Dinas Kependudukan dan Pencatatan Sipil Kabupaten Dairi.

Berdasarkan hasil wawancara dan observasi yang dilakukan oleh peneliti, dapat disimpulkan bahwa biaya pelayanan administrasi kependudukan pada Dinas Kependudukan dan Pencatatan Sipil Kabupaten adalah gratis sesuai dengan Peraturan Bupati Dairi Nomor 03 Tahun 2010 tentang Pedoman dan Tata Cara Pendaftaran Penduduk dan Pencatatan Sipil di Kabupaten Dairi. Petugas pelayanan dalam penerbitan dokumen kependudukan akan dikenakan sanksi organisasi jika melakukan pungutan terhadap pelayanan.

Berdasarkan hasil wawancara dan observasi yang dilakukan oleh peneliti, maka diambil kesimpulan bahwa produk pelayanan dalam hal pendaftaran penduduk pada Dinas Kependudukan dan Pencatatan Sipil Kabupaten Dairi adalah Kartu Keluarga (KK), Kartu Tanda Penduduk elektronik (KTP-el), dan Surat Keterangan Pindah datang. 
Dari hasil telaah dokumen, diperoleh data terkait dokumen kependudukan yang sudah diterbitkan oleh Dinas Kependudukan dan Pencatatan Sipil Kabupaten Dairi sejak Januari sampai dengan April 2017 sebagai berikut:

Tabel 1. Penerbitan Dokumen

Kependudukan bulan Januari s/d Maret 2017

\begin{tabular}{llll}
\hline No. & Jenis Permohonan & $\begin{array}{l}\text { Permoh } \\
\text { onan }\end{array}$ & $\begin{array}{l}\text { Dokumen } \\
\text { yang } \\
\text { diterbitkan }\end{array}$ \\
\hline 1. & Kartu Keluarga & 162 & 145 \\
\hline $2 . \quad \begin{array}{l}\text { Kartu Tanda } \\
\text { Penduduk } \\
\text { elektronik }\end{array}$ & 0 \\
\hline $\begin{array}{l}\text { Surat Keterangan } \\
\text { Pindah Datang }\end{array}$ & 37 & 35 \\
\hline Jumlah & 429 & 180 \\
\hline
\end{tabular}

Sumber: Dinas Kependudukan dan pencatatan SipilKabupaten Dairi, 2017

Tabel 1 menjelaskan bahwa dalam hal penerbitan KK, Surat Keterangan Pindah datang, serta Akta Catatan Sipil tidak mengalami kendala yang terlalu besar. Permohonan yang masuk dengan dokumen yang diterbitkan selisihnya tidak terlalu signifikan. Hal ini dapat disebabkan oleh kekurangan pada berkas pemohon, syaratsyarat yang diperlukan, serta kendala teknis lainnya.

Namun dalam hal penerbitan Kartu Keluarga elektronik (KTP-el), dapat dijelaskan bahwa tidak ada penerbitan KTPel bulan Januari sampai dengan Maret 2017 bahkan sejak bulan Oktober 2016. Hal ini disebabkan oleh ketiadaan blangko KTP-el pada oleh Dinas Kependudukan dan Pencatatan Sipil Kabupaten Dairi.

Berdasarkan hasil wawancara dan observasi peneliti terkait dengan penanganan pengaduan, saran dan masukan dalam hal pendaftaran penduduk pada Dinas kependudukan dan Pencatatan Sipil Kabupaten Dairi, disimpulkan bahwa tidak ada bidang yang khusus menangani permasalahan pengaduan pada Dinas kependudukan dan Pencatatan Sipil Kabupaten Dairi, bahkan tidak tersedia kotak saran dan pengaduan terkait produk, waktu, prosedur, biaya, dan pelayanan yang diterima oleh masyarakat.

Sesuai dengan Undang - Undang Nomor 24 tahun 2013 Tentang Perubahan Atas Undang - Undang No. 23 tahun 2006 Tentang Administrasi Kependudukan, yang dimaksud dengan pencatatan sipil adalah pencatatan Peristiwa Penting yang dialami oleh seseorang dalam register Pencatatan Sipil pada Instansi Pelaksana.

Yang dimaksud dengan peristiwa penting di sini adalah Peristiwa Penting adalah kejadian yang dialami oleh seseorang meliputi kelahiran, kematian, lahir mati, perkawinan, perceraian, pengakuan anak, pengesahan anak, pengangkatan anak, perubahan nama dan perubahan status kewarganegaraan.

Lebih lanjut dalam hal pencatan sipil banyak mengalami perubahan di dalam Undang - Undang Nomor 24 tahun 2013 Tentang Perubahan Atas Undang - Undang No. 23 tahun 2006 Tentang Administrasi Kependudukan.

Perubahan dimaksud antara lain adalah pencatatan kematian, dimana pelaporan pencatatan kematian yang semula menjadi kewajiban penduduk, diubah menjadi kewajiban Rukun Tetangga (RT) untuk melaporkan setiap kematian warganya kepada instansi pelaksana. Pelaporan tersebut dilakukan secara berjenjang melalui Rukun Warga (RW), Desa/Kelurahan dan Kecamatan. Dengan kebijakan ini diharapkan cakupan pencatatan kematian akan meningkat secara signifikan. 
Adapun komponen pelayanan yang digunakan dalam menganalisa pelayanan pencatatan sipil dalam penelitian ini adalah komponen standar pelayanan yang terkait dengan proses penyampaian pelayanan (service delivery) sebagaimana yang dimaksud dalam Peraturan Menteri Pendayagunaan Aparatur Negara dan Reformasi Birokrasi Nomor 15 Tahun 2014 tentang Pedoman Standar Pelayanan meliputi: Persyaratan; Prosedur; Jangka waktu penyelesaian; Biaya/tarif; Produk pelayanan; dan Penanganan pengaduan.

Berdasarkan hasil wawancara dan observasi terkait persyaratan dalam hal pencatatan sipil pada Dinas Kependudukan dan Pencatatan Sipil Kabupaten Dairi, disimpulkan bahwa persyaratan yang ada berdasarkan Peraturan Bupati Dairi Nomor 03 Tahun 2010 tentang Pedoman dan Tata Cara Pendaftaran Penduduk dan Pencatatan Sipil di Kabupaten Dairi. Persyaratan pelayanan telah dilaksanakan dengan baik oleh aparatur pelaksana dan dirasakan mudah oleh masyarakat sebagai penerima layanan.

Dari hasil telaah dokumen diperoleh persyaratan penerbitan akta pencatatan sipil sebagai berikut: Syarat Akta Kelahiran: Melampirkan Surat Kelahiran/Surat Keterangan Lahir dari Dokter/Bidan/penolong kelahiran; Mecatumkan Nama dan Identitas Saksi kelahiran; Melampirkan KK Orang tua; Melampirkan KTP orang tua; Kutipan Akta Nikah/Akta Perkawinan Orang tua; Mengisi formulir yang telah disediakan, dengan menggunakan Formulir model F2.01; dan Khusus bagi kelahiran yang berada di luar domisili, dengan menggunakan for mulir model F2.02
Syarat Akta Perkawinan bagi penduduk yang bukan beragama Islam: Surat keterangan telah terjadinya perkawinan dari pemuka agama/pendeta atau surat perkawinan Penghayat Kepercayaan yang ditandatangni oleh pemuka Penghayat Kepercayaan; KTP Suami dan Istri; Pas photo gandeng suami dan istri ukuran 4 X $6 \mathrm{~cm}$ sebanyak 5 lembar; Kutipan Akta Kelahiran suami dan isteri; Melampirkan KK orang tua suami dan isteri atau KK suami/isteri bagi pelaporan perkawinan yang terlambat; Melampirkan Ijin Pimpinan/Komandan bagi anggota POLRI/ TNI; dan Paspor bagi suami dan isteri orang asing.

Syarat Akta Kematian: Kematian dilaporkan oleh RT/RW, Kepala lingkungan, atau Kepala Desa dan lurah setempat; Formulir pelaporan kematian, dengan menggunakan Formulir model F-2.15; dan Surat keterangan kematian, dengan menggunakan Formulir model F-2.1

Syarat Kutipan Akta Pengangkatan Anak: Menggunakan formulir pencatatan pelaporan pengangkatan anak dengan menggunak an Formulir model F-2.1

Syarat Penerbitan Akta Pengakuan Anak: Formulir pelaporan pengakuan anak, dengan menggunakan Formulir model F2.13; Register akta pengakuan anak; dan Kutipan akta pengakuan anak

Syarat Pencatatan Pengesahan Anak: Menggunakan formulir pencatatan pelaporan pengesahan anak dengan menggunakan Formulir model F-2.14.

Syarat Pencatatan Perubahan Nama : Menggunakan formulir pelaporan perubahan nama kecil/nama keluarga, 
dengan menggunakan Formulir model F2.21

Berdasarkan hasil wawancara dan observasi terkait prosedur dalam hal pencatatan sipil, disimpulkan bahwa prosedur pencatatan sipil pada Dinas Kependudukan dan Pencatatan Sipil Kabupaten Dairi dilaksanakan berdasarkan Peraturan Bupati Dairi Nomor 03 Tahun 2010 tentang Pedoman dan Tata Cara Pendaftaran Penduduk dan Pencatatan Sipil di Kabupaten Dairi.

Adapun kendala yang dihadapi dalam hal prosedur adalah kurangnya sosialisasi Undang - Undang Nomor 24 tahun 2013 Tentang Perubahan Atas Undang - Undang No. 23 tahun 2006 Tentang Administrasi Kependudukan, dimana pelaporan pencatatan kematian yang semula menjadi kewajiban penduduk, diubah menjadi kewajiban Rukun Tetangga (RT) untuk melaporkan setiap kematian warganya kepada instansi pelaksana. Pelaporan tersebut dilakukan secara berjenjang melalui Rukun Warga (RW), Desa/Kelurahan dan Kecamatan.

Dari hasil telaah dokumen, diperoleh data terkait dengan prosedur pencatatan sipil sebagai berikut:
Gambar 3. Prosedur Penerbitan Dokumen Pencatatan Sipil

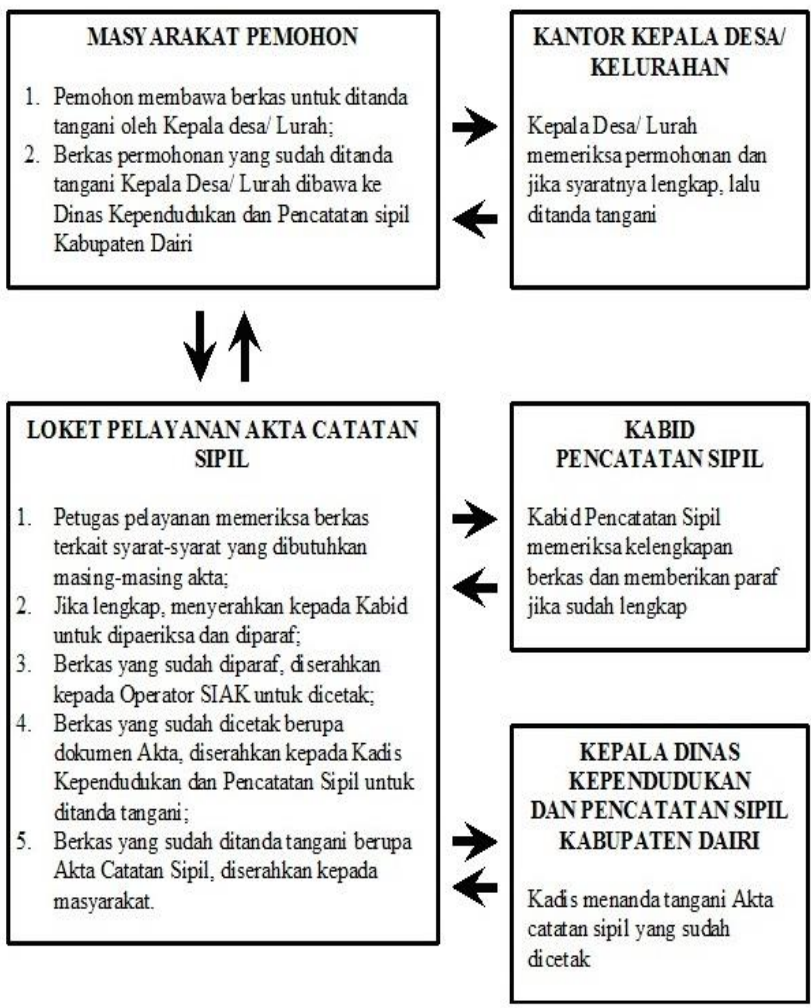

Sumber: Dinas Kependudukan dan pencatatan Sipil Kabupaten Dairi, 2017

Berdasarkan hasil wawancara dan observasi yang dilakukan oleh peneliti, maka diambil kesimpulan bahwa jangka waktu pelayanan pencatatan sipil pada Dinas Kependudukan dan Pencatatan Sipil Kabupaten Dairi adalah 14 hari kerja sesuai Peraturan Bupati Dairi Nomor 03 Tahun 2010 tentang Pedoman dan Tata Cara Pendaftaran Penduduk dan Pencatatan Sipil di Kabupaten Dairi.

Penerbitan akta catatan sipil oleh Dinas Kependudukan dan Pencatatan Sipil Kabupaten Dairi sering mengalami keterlambatan dalam penerbitannya sejak dimohonkan oleh pemohon atau lebih dari 14 hari kerja. Hal ini disebabkan oleh proses penandatanganan akta catatan sipil yang harus ditanda tangani oleh Kepala Dinas Kependudukan dan Pencatatan Sipil Kabupaten Dairi dan tidak dapat diwakilkan. 
Berdasarkan hasil wawancara dan observasi yang dilakukan oleh peneliti, dapat disimpulkan bahwa biaya pelayanan pencatatan sipil pada Dinas Kependudukan dan Pencatatan Sipil Kabupaten sesuai dengan Peraturan Bupati Dairi Nomor 03 Tahun 2010 tentang Pedoman dan Tata Cara Pendaftaran Penduduk dan Pencatatan Sipil di Kabupaten Dairi adalah gratis untuk akta lahir, akta perkawinan yang pelaporannya tidak melebihi 60 hari peristiwa perkawinan, serta akta perceraian yang pelaporannya tidak melebihi 60 hari sejak tanggal perceraian.Untuk pelayanan akta catatan sipil lainnya dikenakan biaya yang bervariasi.

Adapun biaya/retribusi pelayananan pencatatan sipil pada Dinas Kependudukan dan Pencatatan Sipil Kabupaten Dairi, yang diperoleh peneliti melalui telaah dokumen, dapat dilihat dalam tabel berikut ini:

Tabel 2. Retribusi Pelayananan Pencatatan Sipil

\begin{tabular}{|c|c|c|}
\hline No. & Jenis Pelayanan & $\begin{array}{l}\text { Besar Retribusi } \\
\text { (Rp) }\end{array}$ \\
\hline 1. & Pencatatan dan penerbitan kutipan akta kelahiran & $0,-$ \\
\hline 2. & $\begin{array}{l}\text { Pencatatan dan penerbitan kutipan akta perkawinan } \\
\text { Penduduk yang pelapornya belum lewat } 60 \text { (enam puluh) hari sejak tanggal } \\
\text { perkawinan; } \\
\text { Penduduk yang pelapornya telah lewat } 60 \text { (enam puluh) hari sejak tanggal } \\
\text { perkawinan. }\end{array}$ & $\begin{array}{l}0,- \\
25.000,-\end{array}$ \\
\hline 3. & $\begin{array}{l}\text { Pencatatan dan penerbitan akta perceraian } \\
\text { Penduduk yang pelapornya belum lewat } 60 \text { (enam puluh) hari sejak tanggal } \\
\text { diterbitkannya putusan pengadilan yang telah mempunyai kekuatan hukum tetap; } \\
\text { Penduduk yang pelapornya telah lewat } 60 \text { (enam puluh) hari sejak tanggal } \\
\text { diterbitkannya putusan pengadilan yang telah mempunyai kekuatan hukum tetap. }\end{array}$ & $\begin{array}{l}0,- \\
50.000 .-\end{array}$ \\
\hline 4. & Pencatatan dan penerbitan akta kematian & $0,-$ \\
\hline 5. & Penerbitan kutipan akta pengakuan anak & $20.000 .-$ \\
\hline 6. & Pencatatan pengesahan anak & $20.000 .-$ \\
\hline 7. & Penerbitan kutipan akta pengangkatan anak & 20.000 - \\
\hline 8. & Pencatatan perubahan anak & $50.000,-$ \\
\hline 9. & Pencatatan perubahan jenis kelamin & 100.000.- \\
\hline 10. & Pencatatan perubahan kewarganegaraan & 100.000.- \\
\hline
\end{tabular}

Berdasarkan hasil wawancara dan observasi yang dilakukan oleh peneliti, maka diambil kesimpulan bahwa produk pelayanan dalam hal pencatatan sipil pada Dinas Kependudukan dan Pencatatan Sipil Kabupaten Dairi adalah sebagai berikut: Akta Kelahiran; Akta Perkawinan; Akta Perceraian; Akta Kematian; Akta Pengangkatan Anak; Akta Pengakuan Anak; Pencatatan Pengesahan Anak; serta Pencatatan Perubahan Nama.
Adapun kendala dalam hal produk pencatatan sipil adalah masih seringnya terjadi kesalahan data dalam akta catatan sipil yang sudah diterbitkan, namun akan diterbitkan kembali tanpa harus membuat permohonan lagi.

Dari hasil telaah dokumen, diperoleh data terkait akta catatan sipil yang sudah diterbitkan oleh Dinas Kependudukan dan Pencatatan Sipil Kabupaten Dairi sejak Januari sampai dengan Maret 2017 sebagai berikut: 
Tabel 3. Penerbitan Akta catatan Sipil bulan Januari s/d Maret 2017

\begin{tabular}{|c|c|c|c|}
\hline No. & Jenis Permohonan & $\begin{array}{l}\text { Permo } \\
\text { honan }\end{array}$ & $\begin{array}{l}\text { Akta } \\
\text { yang } \\
\text { diterbit } \\
\text { kan }\end{array}$ \\
\hline 1. & Akta Kelahiran & 28 & 25 \\
\hline 2. & Akta Perkawinan & 14 & 14 \\
\hline 3. & Akta Perceraian & 2 & 2 \\
\hline 4. & Akta Kematian & 1 & 1 \\
\hline 5. & $\begin{array}{ll}\text { Akta } & \text { Pengangkatan } \\
\text { Anak } & \\
\end{array}$ & - & - \\
\hline 6. & Akta Pengakuan Anak; & - & - \\
\hline 7. & $\begin{array}{lr}\text { Akta } & \text { Pencatatan } \\
\text { Pengesahan Anak; serta }\end{array}$ & - & - \\
\hline 8. & $\begin{array}{l}\text { Akta Pencatatan } \\
\text { Perubahan Nama. }\end{array}$ & - & - \\
\hline \multicolumn{2}{|c|}{ Jumlah } & 45 & 42 \\
\hline
\end{tabular}

Sumber: Dinas Kependudukan dan pencatatan Sipil Kabupaten Dairi, 2017

Tabel 3 menjelaskan bahwa dalam hal penerbitan Akta Catatan Sipil tidak mengalami kendala yang terlalu besar. Jumlah permohonan yang masuk hampir sama dengan jumlah akta yang diterbitkan, adapun kendala adalah kesalahan dari petugas pemeriksa berkas sehingga berkas dianggap sudah lengkap.

Berdasarkan hasil wawancara dan observasi peneliti terkait dengan penanganan pengaduan, saran dan masukan dalam hal pencatatan sipil pada Dinas kependudukan dan Pencatatan Sipil Kabupaten Dairi, disimpulkan bahwa tidak ada bidang yang khusus menangani permasalahan pengaduan tentang persyaratan, prosedur, waktu, produk, ataupun pelayanan yang diterima oleh masyarakat pada Dinas kependudukan dan Pencatatan Sipil Kabupaten Dairi, bahkan tidak disediakan kotak saran dan pengaduan.

Pelaksanaan Sisitem Informasi Administrasi Kependudukan (SIAK) pada Dinas Kependudukan dan Pencatatan Sipil Kabupaten Dairi
Sesuai dengan Undang - Undang Nomor 24 tahun 2013 Tentang Perubahan Atas Undang - Undang No. 23 tahun 2006 Tentang Administrasi Kependudukan, yang dimaksud dengan Sistem Informasi Administrasi Kependudukan selanjutnya disingkat SIAK, adalah sistem informasi yang memanfaatkan teknologi informasi dan komunikasi untuk memfasilitasi pengelolaan informasi administrasi kependudukan di tingkat Penyelenggara dan Instansi Pelaksana sebagai satu kesatuan.

Adapun komponen pelayanan yang digunakan dalam menganalisa pelayanan administrasi kependudukan dalam penelitian ini adalah Komponen Standar Pelayanan yang terkait dengan proses pengelolaan pelayanan di internal organisasi (manufacturing) meliputi: 1) Sarana dan prasarana; 2) Kompetensi pelaksana; 3) Jumlah pelaksana

Berikut ini adalah informasi dan data yang diperoleh oleh peneliti beserta pembahasannya sebagai berikut: 1) Sarana dan Prasarana Pelaksanaan Sistem Informasi Administrasi Kependudukan (SIAK). Berdasarkan hasil wawancara dan observasi yang dilakukan oleh peneliti, dapat disimpulkan bahwa sarana dan prasarana pelaksanaan Sistem Informasi Administrasi Kependudukan (SIAK) pada Dinas kependudukan dan Pencatatan Sipil Kabupaten Dairi tidak memadai. 2) Adapun kendala dalam pelaksanaannya adalah: Kurangnya sarana pendukung kerja seperti komputer dan printer untuk operator SIAK yang ada di Dinas Kependudukan dan Pencatatan Sipil Kabupaten Dairi maupun operator Tempat Perekaman Data Kependudukan (TPDK) Kecamatan; Hampir 50 persen tower pemancar frekuensi radio 
yang ada di TPDK Kecamatan dalam kondisi rusak, sehingga proses pengiriman data kepada server di Dinas Kependudukan dan Pencatatan Sipil Kabupaten Dairi dilakukan dengan cara manual yaitu melalui penyimpanan dengan menggunakan memory eksternal; Database SIAK yang menyimpan data kependudukan seluruh penduduk Kabupaten Dairi masih dianggap kurang performance-nya. Saat ini, untuk proses back-up data masih dilakukan dengan menggunakan harddisk eksternal. Proses back-up dilakukan pada sore hari saat seluruh proses transaksi data sudah selesai. Hal tersebut dinilai tidak praktis dan masih tradisional mengingat pada instansi swasta, seperti Bank, sudah melakukan back-up secara real time ketika transaksi data nasabah dilakukan.

Kompetensi Pelaksana Sistem Informasi Administrasi Kependudukan (SIAK), berdasarkan hasil wawancara dan observasi yang telah dilakukan, maka diambil kesimpulan bahwa kompetensi pelaksana dalam pelaksanaan Sistem Informasi Administrasi Kependudukan (SIAK) pada Dinas kependudukan dan Pencatatan Sipil Kabupaten Dairi, belum terlaksana dengan baik. Operator yang direkrut untuk mengoperasikan SIAK belum seluruhnya memiliki kemampuan, kompetensi, keahlian, keterampilan, sikap, dan perilaku yang dibutuhkan dalam pelaksanaan tugas. Sehinggga dibutuhkan pelatihan yang berkesinambungan bagi aparatur pelaksana terkait tugas pokok dan fungsinya masing-masing.

Jumlah Pelaksana Sistem Informasi Administrasi Kependudukan (SIAK), berdasarkan hasil wawancara dan observasi yang dilakukan, dapat disimpulkan bahwa jumlah pelaksana dalam pelaksanaan Sistem Informasi Administrasi Kependudukan (SIAK) pada Dinas kependudukan dan Pencatatan Sipil Kabupaten Dairi, belum memadai. Seharusnya operator yang ada pada Tempat Perekaman Data Kependudukan (TPDK) kecamatan minimal ada 2 orang, sedangkan operator yang ada di Dinas Kependudukan dan Pencatatan Sipil kabupaten Dairi seharusnya ada 15 orang dengan rincian 1 orang untuk menangani setiap kecamatan.

\section{SIMPULAN}

Pelayanan pendaftaran penduduk pada Dinas Kependudukan dan Pencatatan Sipil Kabupaten Dairi sudah dilaksanakan dengan baik dalam hal persyaratan, prosedur, dan biaya/ tarif. Persyaratan yang ada dirasakan cukup mudah, prosedur yang ada jelas dan dirasakan tidak memberatkan masyarakat, sementara biaya/ tarif pelayanan adalah gratis.

Kendala pertama yang ditemui dalam pelaksanaan pendaftaran penduduk adalah adalah dalam hal jangka waktu, sebagaimana yang telah ditetapkan dalam Undang - Undang Nomor 24 tahun 2013 Tentang Perubahan Atas Undang - Undang No. 23 tahun 2006 Tentang Administrasi Kependudukan jangka waktu penerbitan dokumen kependudukan sejak dimohonkan adalah 14 hari kerja, namun pada kenyataannya sering mengalami keterlambatan penerbitan. Hal ini disebabkan oleh proses penandatanganan yang tidak dapat diwakilkan serta tidak adanya blangko Kartu Tanda Penduduk elektronik (KTP-el).

Kedua adalah dalam hal produk pelayanan, kendala yang dialami adalah 
kesalahan data pada dokumen kependudukan yang sudah diterbitkan, serta ketiadaan blangko blangko Kartu Tanda Penduduk elektronik (KTP-el).

Kendala ketiga adalah dalam hal penanganan pengaduan, belum ada bidang khusus yang menangani pengaduan terkait pendaftaran penduduk pada Dinas Kependudukan dan Pencatatan Sipil kabupaten Dairi.

Pelayanan pencatatan sipil pada Dinas Kependudukan dan Pencatatan Sipil kabupaten Dairi sudah terlaksana dengan baik dalam hal persyaratan, dan biaya/ tarif. Persyaratan yang ada dirasakan cukup mudah, jelas dan tidak memberatkan masyarakat, sementara biaya/ tarif pelayanan adalah gratis untuk Akta Kelahiran, Akta Kematian, Akta Pernikahan yang dilaporkan kurang dari 60 hari dari tanggal penikahan, serta Akta Perceraian yang dilaporkan sebelum 60 hari dari tanggal perceraian. Sementara untuk akta catatan sipil lainnya dikenakan tarif yang bervarisasi.

kendala dalam pelayanan pencatatan sipil dalam hal prosedur, adalah kurangnya sosialisasi Undang-Undang Nomor 24 tahun 2013 Tentang Perubahan Atas Undang Undang No. 23 tahun 2006 Tentang Administrasi Kependudukan, dimana pelaporan pencatatan kematian yang semula menjadi kewajiban penduduk, diubah menjadi kewajiban Rukun Tetangga (RT) untuk melaporkan setiap kematian warganya kepada instansi pelaksana. Pelaporan tersebut dilakukan secara berjenjang melalui Rukun Warga (RW), Desa/Kelurahan dan Kecamatan.

Dalam hal jangka waktu, sebagaimana yang telah ditetapkan dalam Undang Undang Nomor 24 tahun 2013 Tentang
Perubahan Atas Undang - Undang No. 23 tahun 2006 Tentang Administrasi Kependudukan jangka waktu penerbitan akta catatan sipil adalah 14 hari kerja sejak dimohonkan, namun pada kenyataannya sering mengalami keterlambatan penerbitan. Hal ini disebabkan oleh proses penandatanganan yang harus ditanda tangani langsung oleh Kepala Dinas Kependudukan dan Pencatatan Sipil Kabupaten Dairi dan tidak dapat diwakilkan;

Dalam hal produk pelayanan, kendala yang dialami adalah kesalahan data pada dokumen kependudukan yang sudah diterbitkan. Hal ini dapat disebabkan oleh kesalahan pengisian data dari masyarakat ataupun kesalahan pengisian data oleh operator SIAK pencatatan sipil;

Dalam hal penanganan pengaduan, belum ada bidang khusus yang menangani pengaduan terkait pencatatan sipil pada Dinas Kependudukan dan Pencatatan Sipil kabupaten Dairi.

Pelaksanaan Sistem Informasi Administasi Kependudukan (SIAK) pada Dinas Kependudukan dan Pencatatan Sipil Kabupaten Dairi belum berjalan dengan baik dalam hal sarana dan prasarana, kompetensi pelaksana, dan jumlah pelaksana.

Adapun kendala dalam pelaksanaannya adalah sebagai berikut: Dalam hal sarana dan prasana, adalah kurang memadainya sarana dan prasarana pendukung kerja seperti komputer, printer, tower pemancar frekuensi radio, serta Database SIAK yang kurang performanya; Kompetensi pelaksana dalam pelaksanaan Sistem Informasi Administrasi Kependudukan (SIAK) pada Dinas kependudukan dan Pencatatan Sipil 
Kabupaten Dairi, belum terlaksana dengan baik. Operator yang direkrut untuk mengoperasikan SIAK belum seluruhnya memiliki kemampuan, kompetensi, keahlian, keterampilan, sikap, dan perilaku yang dibutuhkan dalam pelaksanaan tugas. Jumlah pelaksana dalam pelaksanaan Sistem Informasi Administrasi Kependudukan (SIAK) pada Dinas kependudukan dan Pencatatan Sipil Kabupaten Dairi, masih kurang dan belum memadai.

\section{DAFTAR PUSTAKA}

Anwari, 200o. Motivasi: Perangkat Analisis Untuk Para Manajer. Usahawan, No. 12, Th. XXIX, Desember. Hal. 34-40

Arep, I., dan Hendri T., 2003. Manajemen Dan Motivasi 2003. Jakarta: Grasindo

As'ad, M., 1991. Psikologi Industri, Yogyakarta: Liberty.

Baswartono, 1997. Mengkaji Ulang Hubungan Antara Motivasi, Manajemen dan Produktivitas. Usahawan, No. 09, Thn. XXVI, September. Hal. 31-32

Gibson, J.L., Ivancevich, John M., and Donelly JR, James H., 1997. Organisasi: Perilaku, Struktur, Proses. (Alih bahasa: Nunuk Adiarni), Edisi Kedelapan, Jakarta : Binarupa Aksara.

Handoko, T.H., 1986. Manajemen, Edisi Kedua, Yogyakarta: BPFE

Handoko, T. Hani, 1988. Manajemen Personalia dan Sumber Daya Manusia, Edisi Kedua. Yogyakarta: -BPFE

Hasibuan, M.S.P., 2002. Manajemen: Dasar Pengertian dan Masalah, Edisi Revisi. Jakarta: PT. Gunung Agung,

Irianto, J., 1994. Upaya Meningkatkan Semangat Kerja: Suatu Tinjauan Teoritik Aliran Hubungan Kemanusiaan (Rubrik: Perkembangan Teori). Usahawan, No. 04, Thn. XXIII, April. Hal. 2-5

Mangkunegara, A.A. Anwar P, 200o. Manajemen Sumber Daya Manusia Perusahaan. Bandung: Rosda.

Mangkuprawira, S., 2002. Manajemen Sumber Daya Manusia Strategik. Jakarta: Ghalia Indonesia
Muchlas, M., 1999. Perilaku Organisasi. Cetakan ke 1. Yogyakarta: Program Pendidikan Pascasarjana Magister Manajemen Rumah Sakit Universitas Gadjah Mada Yogyakarta

Reksohadiprodjo, S., dan Handoko, T.H., 1986. Organisasi Perusahaan: Teori, Struktur dan Perilaku, edisi kedua, Yogjakarta: BPFE.

Sigit, S., 2002. Pengantar Metodologi Penelitian Sosial-Bisnis-Manajemen. Edisi 2.

Sinaga, R., 1991, Motivasi Sumber Daya Manusia Untuk Meningkatkan Produktivitas. Usahawan, No. 11, Thn. XX, Nopeinber. Hal. 29-33

Simamora, H., 1997. Manajemen Sumber Daya Manusia. Edisi Ke 2, Yogyakarta: BP-STIE YKPN

Sulistiyani, A.T., dan Rosidah. 2003. Manajemen Sumber Daya Manusia. Yogyakarta: Graha llmu

Smvarto, FX., 1999. Perilaku Keorganisasian: Buku Panduan Mahasiswa. Yogyakarta: Universitas Atmajaya.

Syatarudin, A., 2001. Manajemen Sumber Daya Manusia: Strategi; keunggulan Kompetitif,. Edisi Pertama. Yogyakarta: BPFE

Umar, H., 2001 Riset Sumber Daya Manusia Dalam Organisasi Jakarta: Gramedia Pustaka Utama

Wahyusumidjo, 1984. Kepemimpinan dan Motivasi, Jakarta: Ghalia Indonesia. 